\title{
Crisis Points
}

Editors: Ian Taylor and Jock Young

The impact of the last five years of economic and political crisis in Britain appears to have dulled the nerve and commitment of the 'informed' political and social critic. 'Inevitable progress', 'benign capitalism', 'the politics of consensus' - the clichés of the sixties are still paraded as the conventional wisdom of the seventies. One consequence of this has been a dearth of informed and incisive discussion of issues such as the decline of educational, health and welfare services, the impact of inflation on living standards, physical fitness and nutrition and the everyday experience of poverty, illness, racism and crime in present-day Britain. This series focuses on the erosion of both the social and the political rights of the individual: for the decline in living standards is mirrored by the threat of new legislation and police powers to the freedom of the individual. Such a tightening of the reins of control has its cultural manifestation whether it is in the appearance of a new McCarthyism in the media and the universities or in the signs of resistance in youth culture and the new wave of popular music.

The Crisis Points series aims to rectify this gap in contemporary debate. The books are written from the inside by practitioners or activists confronting the crisis in their field of work; they are informed in their content not academic in their style; and they are accessible to the increasing numbers of the public concerned with the social problems of our times. Above all they are short and provocative - a basis of debate, whether it be in the home, classroom or workplace. 
Titles in the Crisis Points series

Published

Schooling the Smash Street Kids

Paul Corrigan

Trapped within Welfare:

Surviving Social Work

Mike Simpkin

Health in Danger: the Crisis in the National Health Service

David Widgery

Forthcoming

Leisure and Work

John Clarke and Chas Critcher

Who Needs Housing?

Jane and Roy Darke

Who Owns the Media?

Graham Murdock

Hooliganism

Geoff Pearson

The Beautiful Child

Lee Reber 


\section{Trapped within Welfare \\ Surviving Social Work}

Mike Simpkin 
(C) Mike Simpkin 1979

All rights reserved. No part of this publication may be reproduced or transmitted, in any form or by any means, without permission.

First published 1979 by

THE MACMILLAN PRESS LTD

London and Basingstoke

Associated companies in Delhi Dublin

Hong Kong Johannesburg Lagos Melbourne

New York Singapore and Tokyo

\section{British Library Cataloguing in Publication Data}

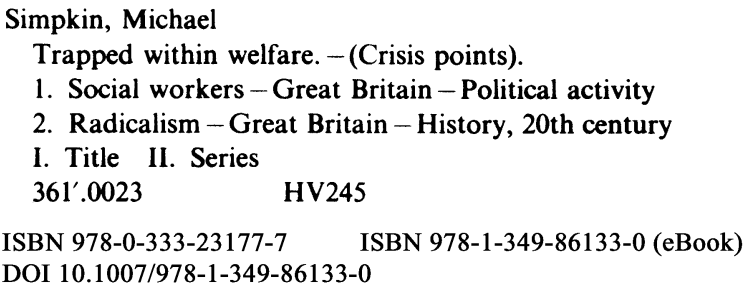

This book is sold subject to the standard conditions of the Net Book Agreement.

The paperback edition of this book is sold subject to the condition that it shall not, by way of trade or otherwise, be lent, resold, hired out, or otherwise circulated without the publisher's prior consent in any form of binding or cover other than that in which it is published and without a similar condition including this condition being imposed on the subsequent purchaser. 


\section{Contents}

Acknowledgements viii

Introduction Social work: profession of the seven veils 1

\section{Part I Social Work and Social Policy}

1. The pricking of the social work bubble 9

Social work as the universal provider 12

The Seebohm compromise $\quad 15$

$\begin{array}{ll}\text { The Seebohm factories } & 17\end{array}$

The advent of radical social workers $\quad 20$

Disillusion and retrenchment 22

2. Social work, the state and social control 26

Pluralism: the state disguised $\quad 30$

The state as the instrument of class 31

Ideology: the permeative stabiliser $\quad 37$

Are we trapped by original sin? 38

The radical dilemma $\quad 39$

\section{Part II The Welfare Trap}

3. Not clients but workers 45

Social-working the working class $\quad 47$

Crushed by conventional simplicity $\quad 49$

Client accumulation $\quad 52$

Individualisation: the easier answer 57

The extent of inequality 58

Welfare: from workers' privilege to workers' burden $\quad 65$ 
vi Contents

Vulnerability

At-risk populations $\quad 67$

What about the losers? $\quad 70$

Alienation and dependence $\quad 71$

4. Blinkered self-denial 72

I, social worker $\quad 74$

Disentangling motives $\quad 75$

$\begin{array}{ll}\text { Putting up the shutters } & 80\end{array}$

The siege mentality $\quad 81$

Rites of passage $\quad 82$

Leading by the nose $\quad 83$

Blowing the gaff $\quad 84$

5. The lament for caring 86

$\begin{array}{ll}\text { Retreat into casework } & 87\end{array}$

Deskilling and the division of labour 93

Immanuel Kant, unsung patriarch of social work values $\quad 95$

The false credibility of the caring ideology 100

The rule of expediency 103

Caring as moral and political control 104

Individuals and families: production and reproduction 105

$\begin{array}{ll}\text { The unequal relationship } & 108\end{array}$

$\begin{array}{ll}\text { Escape routes } & 109\end{array}$

\section{Part III Practical Strategies}

6. Striving for technical solutions 113

$\begin{array}{ll}\text { Managerialism } & 114\end{array}$

$\begin{array}{ll}\text { Professionalism } & 117\end{array}$

Paths to professional status 118

$\begin{array}{ll}\text { The mistaken search for exclusive knowledge } & 120\end{array}$

Authority and status $\quad 124$

$\begin{array}{ll}\text { Professionals or bureaucrats? } & 126\end{array}$

$\begin{array}{ll}\text { The impossibility of a pure professional social work } & 129\end{array}$

7. The radical challenge 132

Labelling, deviancy theory and anti-psychiatry 133

Politics and madness 134

$\begin{array}{ll}\text { Community work } & 137\end{array}$

Libertarian social work $\quad 138$ 
The problem of money $\quad 139$

Stealing libertarian clothes $\quad 139$

Overcoming isolation 141

Foundations of a Marxist strategy 143

Joining the union 144

Unions and politics 148

$\begin{array}{ll}\text { Politics and social workers } & 149\end{array}$

8. Opening out: limits and contradictions 152

Is radicalism viable? 153

The use of statutory powers $\quad 153$

Client refusal 154

Recognition and negotiation: towards a political praxis $\quad 155$

Collective work $\quad 157$

Fumigating ourselves of social work assumptions $\quad 158$

$\begin{array}{ll}\text { Where do we go from here? } & 159\end{array}$

$\begin{array}{ll}\text { Notes and references } & 161\end{array}$ 


\section{Acknowledgements}

Many people have contributed to the ideas expressed in this book, so I make no claims to originality. Particular thanks must go to the early members of the Editorial Collective of Case Con, who enabled me to see the value of a more radical perspective after my liberalism had been shredded by my post-Seebohm experience. I am also grateful to my present colleagues, especially Wally Reed, for their moral support, if not their total agreement, and to Paul Corrigan and Peter Leonard for allowing me to see advance proofs of their new book Social Work Practice under Capitalism. Ian Taylor suggested the book and his comments have saved me from at least some political and stylistic solecisms; Tim Fox at Macmillan was of great help at the copy-editing stage. My greatest debt is to Carole Dale, whose imagination and perseverance have not only ensured completion of the book, but also provided much of its inspiration. Needless to say, any mistakes are my responsibility. 